\title{
Psychometric properties of the Persian version of the Sexual and Reproductive Health Needs Assessment Questionnaire
}

\author{
S. Khani, ${ }^{1}$ L. Moghaddam-Banaem, ${ }^{1}$ E. Mohamadi, ${ }^{2}$ A.A. Vedadhir ${ }^{3}$ and E.Hajizadeh ${ }^{4}$
}

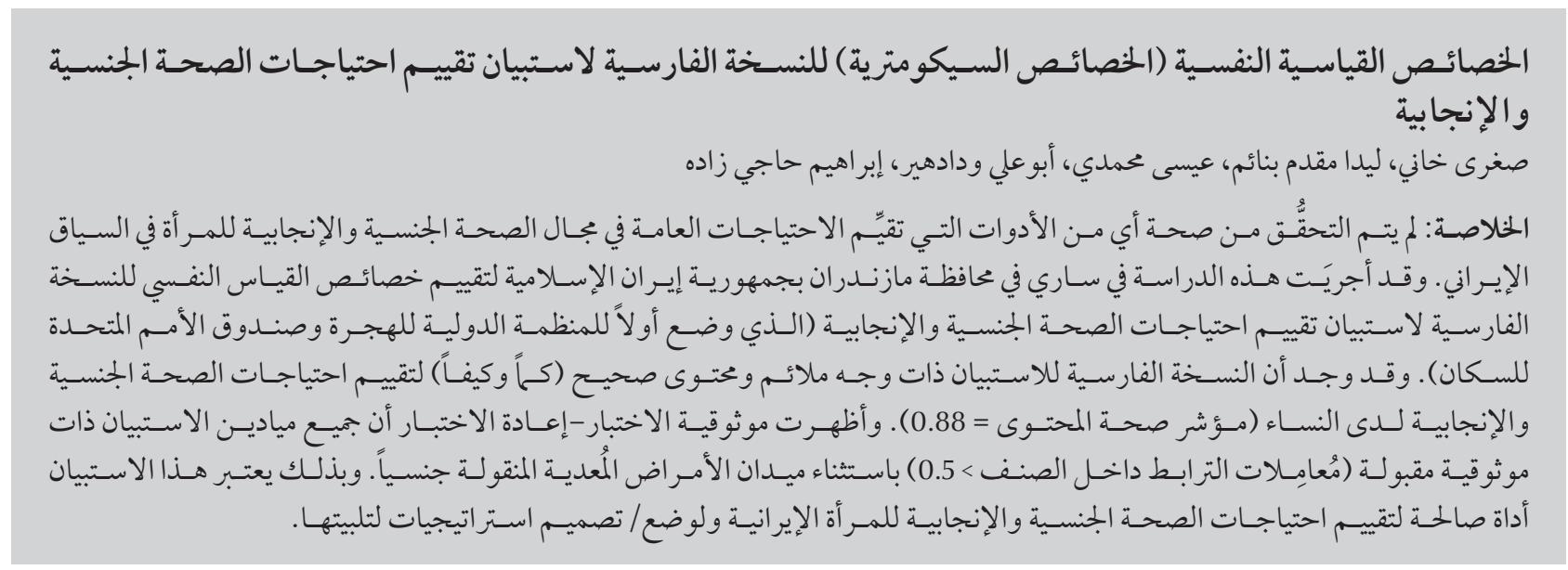

ABSTRACT No tools to assess women's general sexual and reproductive health needs have been validated in the Iranian context. This study in Sari in Mazandaran province of the Islamic Republic of Iran was conducted to evaluate the psychometric properties of a Persian version of the Sexual and Reproductive Health Needs Assessment Questionnaire (first developed for the International Organization for Migration and United Nations Population Fund). The Persian version of the questionnaire was found to have adequate face and content validity (quantitative and qualitative) for assessing sexual and reproductive health needs among women (content validity index $=0.88$ ). The test-retest reliability showed that, except for the domain of sexually transmitted infections, all domains of the questionnaire had an acceptable reliability (intra-class correlation coefficients $>0.5$ ). This questionnaire is a valid tool for assessing the sexual and reproductive health needs of Iranian women and planning/designing strategies to meet them.

Propriétés psychométriques de la version en langue perse du Sexual and Reproductive Health Needs Assessment Questionnaire évaluant les besoins en santé sexuelle et génésique

RÉSUMÉ Dans le contexte iranien, aucun outil évaluant les besoins généraux en santé sexuelle et génésique des femmes n'a été validé. La présente étude à Sari, dans la province de Mazandaran (République islamique d'Iran), a été menée afin d'évaluer les propriétés psychométriques de la version en langue perse du Sexual and Reproductive Health Needs Assessment Questionnaire (initialement élaboré pour l'Organisation internationale pour les migrations et le Fonds des Nations Unies pour la population). Il a été estimé que la version en langue perse du questionnaire avait une validité apparente et de contenu adéquate (quantitative et qualitative) pour évaluer les besoins en santé sexuelle et génésique des femmes (indice de validité de contenu =0,88). La fiabilité d'un test-retest a démontré qu'à l'exception du domaine des infections sexuellement transmissibles, tous les domaines du questionnaire avaient une fiabilité acceptable (coefficients de corrélation intra-classe $>0,5$ ). Le questionnaire est un outil valable pour évaluer les besoins en santé sexuelle et génésique des femmes iraniennes et pour prévoir/élaborer des stratégies qui y répondent. 


\section{Introduction}

Each person has the right to have satisfying reproductive and sexual activities, free of violence or coercion $(1,2)$. Women's health directly affects long-term development programmes in any country (3) and meeting women's sexual and reproductive health (SRH) needs plays an important role in social health provision and promotion (4). Despite the outstanding progress in health care in the Islamic Republic of Iran, some deficiencies in the provision of sexual health services in health-care centres have been noted, which might be attributed to sociocultural barriers (5). Accurate determination of unmet needs is necessary to address these deficiencies and plan for better reproductive services for women (6). In order to properly assess any aspect of health needs in the community a culturally appropriate tool is required in the language of that community (7). It is hoped that use of appropriate tools to determine women's SRH needs, and meeting those needs, will lead to reduced mortality and morbidity in women and children (8).

Health needs assessment is a systematic method for reviewing health challenges in a society, leading to the identification of priorities and better allocation of resources to promote health and reduce health inequities (9). Our review of studies conducted in the Islamic Republic of Iran revealed that many of the tools used to define SRH needs were specific to particular groups - such as pre-marriage couples (10), students $(11,12)$, people living with HIV/AIDS (12) and adolescents (13) — and there were no general SRH needs assessment tools that had been validated in the Iranian context. We therefore decided to adapt and test an international standard questionnaire for assessing women's SRH needs in a northern area of the Islamic Republic of Iran.
For this study we selected the SRH Needs Assessment Questionnaire, which was designed by New Dimension Consulting (NEDICO) for the International Organization for Migration and the United Nations Population Fund to be used among mobile and vulnerable populations in Zimbabwe $(14,15)$. It covers needs in various domains of reproductive health including safe motherhood, family planning, sexual behaviours, sexually transmitted infections (STIs), HIV/AIDS and physical and sexual violence. The questionnaire is similar to the Reproductive Health Assessment Questionnaire for Conflict-Affected Women developed by the United States Centers for Disease Control and Prevention (CDC) (16). The SRH Needs Assessment Questionnaire, however, is slightly shorter and easier than the CDC questionnaire in terms of understanding and completion by participants, coding, data entry and data analysis. This study in Mazandaran province of the Islamic Republic of Iran was conducted to evaluate the psychometric properties of a Persian version of the questionnaire, with a focus on the assessment of face and content validity and reliability of the instrument.

\section{Methods}

\section{Study setting}

This psychometric study was carried out from July 2012 to May 2013. The study was conducted in Sari, the largest city of Mazandaran province in the north of Islamic Republic of Iran. This is a region which has higher scores on favourable reproductive health indices compared with the whole country, e.g. percentage of pregnant women with at least 6 prenatal care visits $(81.6 \%$ in Islamic Republic of Iran versus $93.9 \%$ in Mazandaran), contraception methods use in reproductive ages ( $77.4 \%$ versus $79.6 \%$ respectively) and percentage of women who receive at least one postnatal care visit $(73.9 \%$ versus $76.3 \%$ respectively) (17). Sari, in the centre of Mazandaran, was selected for the study, so that the final Persian version of the tool would meet higher than average Iranian standards.

\section{Questionnaire}

Consent to create and test a Persian version of the SRH Needs Assessment Questionnaire (14) was obtained from the deviser of the questionnaire (NEDICO). The questionnaire is a 114-item English-language instrument consisting of background information (15 items), safe motherhood (35 items), family planning (16 items), sexual history and function (10 items), STIs (8 items), HIV/AIDS (14 items) and violence against women (16 items).

\section{Translation}

Translation was a 5-stage process. Stage 1 was to translate the English questionnaire into Persian, using the decentred or symmetric method of translation $(18,19)$. In this method, the researcher avoided verbatim translation to be able to implement cultural and social considerations and modifications in the original version. The process of cultural adaptation was supervised by the researchers throughout all phases of the study. The forward-backward procedure was applied for translation (20). Two competent English language translators translated the questionnaire from English to Persian.

Stage 2 was back-translation. The 2 Persian versions were translated back into English by 2 other translators who had no access to the original version. Stage 3 was synthesis into one version of the translated questionnaire. The research group compared and revised these 2 versions of the questionnaire and their items, in order to generate an appropriate version. Stage 4 was a review by an expert committee. The final English version and original questionnaire were compared item-by-item and in general by 2 other English language and SRH experts, and they confirmed 
the similarity of the 2 versions. Stage 5 was testing of the tool, in which the validity (face and content) and reliability were assessed.

\section{Participants}

A total of 21 SRH experts and 17 female clients participated in 4 focus group discussions to assess the qualitative content validity of the questionnaire.

A sample of 60 women attending health-care and behavioural diseases consultation centres of Sari, Mazandaran, Islamic Republic of Iran participated in the test-retest phase to assess reliability. Women eligible for the study were of reproductive age (15-49 years) and married at least once. All women were selected through a convenience sampling method and were interviewed face-to-face after a brief explanation about the aims of the study and obtaining their written consent to participate in the study. The interview was performed by one midwife in each centre who read each item from her copy and let the participant chose the appropriate response in her own copy of the questionnaire. For illiterate women, the questionnaire was filled in by the interviewer.

\section{Analysis of validity and reliability}

All statistical procedures were conducted using SPSS, version 19. Face validity, content validity and reliability of the questionnaire were assessed as follows:

\section{Face validity}

Both qualitative and quantitative methods were used for assessing the face validity of the questionnaire. To examine qualitative face validity, 11 reproductive health experts assessed the questionnaire, including the head of the family health department of Mazandaran University of Medical Sciences, an expert from behavioural diseases consultation centres, a social medicine physician, 2 reproductive health experts, a health education expert, a maternal and child health physician, a medical sociologist, an expert with a nursing $\mathrm{PhD}$ and 2 midwives.

A total of 24 women attending health centres of Sari were interviewed to express their opinions about the appearance of the questionnaire. Then, in the quantitative approach to face validity, impact scores (frequency $x$ importance) were determined by the percentage of participants who identified each item of the questionnaire as extremely important, very important, important, little importance or not important at all. Scores of 5-1 were allocated to these levels respectively.

Data were entered into the computer and the impact scores given by all subjects were totalled. Impact scores > 1.5 were considered acceptable (21).

\section{Content validity}

Two methods (qualitative and quantitative) were used to assess content validity. In the quantitative phase, 2 indicators of content validity assessment were measured: content validity ratio (CVR) and content validity index (CVI).

First, to assess content validity by CVR, 10 experts (who were not from the previous group) were asked to evaluate each item of the questionnaire according to a 3-point scale (necessary, useful but not necessary or not necessary) and the CVR was calculated for each item. According to Lawsche, items with CVR > 0.62 (based on 10 experts' evaluation) were kept and considered significant (22).

To assess content validity by CVI the method of Waltz and Bausell was used (23). The main researcher presented the Persian version of the questionnaire to $15 \mathrm{SRH}$ specialists (who were not the experts in previous stages) and requested them to assess the relevancy of each item or statement in the questionnaire. The relevancy criteria were assessed in the format of a 4-point Likert scale for each item: irrelevant, nearly relevant, relevant and totally relevant. The experts evaluated 3 aspects of the questionnaire - each single item, each domain of SRH and the overall questionnaire-checking for the grammar, wording, item allocation, scaling and any needed modifications, eliminations or additions to the questionnaire. Every point made by the experts was applied and made available to the research group. After discussing these views, they would decide which modifications to implement.

In order to confirm whether the questionnaire still needed modifications in content, 2 focus group discussions were held with 17 women attending health centres as main beneficiaries and 2 panels of SRH experts. The questionnaire modified by the previous stages translation, adaptation, face and content validations - was made available to them. Each item was read and members expressed their opinions. After reaching a consensus of all members present, that particular item was registered in the questionnaire.

\section{Reliability}

The reliability of the questionnaire was assessed using the test-retest method. This was conducted to assess the questionnaire's stability by estimating and interpreting the intra-class correlation coefficient (ICC) (24). A total of 60 women completed the questionnaire twice in 2-week intervals. Then, scores of these 2 stages were compared and ICC values of $\geq 0.40$ were considered satisfactory (24).

\section{Ethical considerations}

An informed written consent consisting of the general conditions of the study and its applications was obtained from all participants, they were all assured about the preservation of the privacy and confidentiality of their information and comments, and the questionnaires were completed anonymously (without asking the name of the participants or knowing the participant beforehand). The World Health Organization's 
(WHO) ethical and safety recommendations for research on domestic violence against women were also applied (25). The research design of this study was approved by the ethics committee of Tarbiat Modares University. For any stages of the study that required contacting participants, an introductory letter was obtained from the research deputy of Tarbiat Modares University and the health deputy of Mazandaran University of Medical Sciences.

\section{Results}

\section{Translation and adaptation of the questionnaire}

Several changes were made in this phase with regard to items about education, religion, childbirth, health care and pregnancy services provided, abortion sites and HIV/AIDS services; these were modified in accordance with the rules of the Iranian Ministry of Education, as well as the religious beliefs and culture of Iranians, and the existing regulations of the health-care system of the country.

Marital status and age of participants at first marriage were asked before enquiring about pregnancy, childbirth and number of children. Due to the confidential and private nature of the questions about sexual violence, as well as to gain the confidence of participants, the order of questions related to physical violence (nos. 109-114) was swapped with questions about sexual violence (nos. 99-108).

In questions nos. 62-66 "female condom" was changed to "condom", given that this type of condom is not usually used in Islamic Republic of Iran. Also, question no. 72, "What type of condom have you used so far?", was omitted (Table 1).

\section{Validity assessment}

In qualitative face validity, the length of the questionnaire and its tabulated form were assessed by 11 reproductive health experts and 24 participants, and the table format of the questionnaire was converted to common numbered format. Question no. 26 ("Who assisted you to deliver at the health centre?") and question no. 27 ("Who assisted you to deliver at home?") were merged into one question: "Delivery agent (in your last delivery)".

In qualitative face validity, 21 questions were reworded or modified (Table 2) and 4 questions about the demographic characteristics of the woman's husband were added: husband's age, education level, job and household's monthly income.

In quantitative face validity, the total mean impact score was 4.24. The impact score was $<1.50$ for 5 questions, all of which were omitted. Lack of availability of female condoms, lack of diversity in religion in the people of this part of Islamic Republic of Iran, application of this tool for fixed populations rather than mobile/refugee camp populations and the fact that there are very few cases of adoption in the country were the reasons for omitting the questions with impact score < 1.5 (Table 1).

The overall CVR score of the questionnaire was 0.87 . A total of 6 questions with CVR $<0.62$ were omitted (Table 1).

The overall CVI of the questionnaire was 0.88 . The CVIs obtained for all the constructs of the questionnaire were as follows: background variables $=0.70$, safe motherhood $=0.82$, family planning $=0.90$, sexual behaviour and history $=0.73$, sexually transmitted diseases $=1.00, \mathrm{HIV} / \mathrm{AIDS}=1.00$ and violence against women $=1.00$. All questions had CVI $\geq 0.70$ and thus no questions were omitted in this stage.

In qualitative content validity the following modifications were implemented at this phase of assessment of content analysis: The "no response" option was omitted from all answer items. In the section on background characteristics, 2 questions (nos. 11 and 12) were merged into one question, and 2 open-ended questions about job were replaced by a close-ended question with 10 response items (Table 2). In the 2 nd construct, in 4 questions (nos. 51-54) "abortion" was excluded from the contraception methods in line with WHO guidelines (26), and 7 questions on unwanted pregnancy were added (Table 2).

In the focus group discussions and expert panels the following modifications were implemented. In the section on background characteristics, spouse's sociodemographic characteristics were added (i.e. age, education and occupation) and some general information (i.e. family income per month and total expenditure of the household per month). In the 1 st construct, a question was reworded according to the experts' opinions. In the 2nd construct, one more question was also edited. In the 5th construct, the options of 5 questions (nos. 86, 88, 89, 90 and 98) were edited, and 2 questions (nos. 91 and 92) were changed into options in one question (no. 90) about modes of HIV/AIDS transmission (in which only the correct modes were included and the rest were omitted, because when there are both correct and incorrect transmission routes of HIV as options in one question, participants may assume all of them are correct). In the 6th construct, 6 questions (nos. 99, 103, 104, 108, 109 and 114) were reworded as well. Table 1 shows the questions omitted from the tool in various phases and the reasons for their omission. The reworded or modified items of the tool are presented in Table 2.

\section{Reliability assessment}

A total of 60 women participated in the test-retest phase. The mean age of the participants was 31 (standard deviation 7.8) years. A majority of them were housewives (76.3\%) and the highest level of educational attainment in 38.4\% 


\begin{tabular}{|c|c|c|c|c|c|c|}
\hline Order & $\begin{array}{l}\text { Item } \\
\text { no. }\end{array}$ & Item & Stage & Index ${ }^{a}$ & Score & Reasons for omission \\
\hline 1 & 72 & $\begin{array}{l}\text { Which type of condom did } \\
\text { you use? }\end{array}$ & Adaption & - & - & $\begin{array}{l}\text { Female condoms are not available in } \\
\text { Islamic Republic of Iran }\end{array}$ \\
\hline 2 & 3 & What is your religion? & $\begin{array}{l}\text { Quantitative face } \\
\text { validity }\end{array}$ & $\begin{array}{l}\text { Impact } \\
\text { score }\end{array}$ & 1.47 & $\begin{array}{l}\text { Most people in this part of I.R. Iran are } \\
\text { Muslims }\end{array}$ \\
\hline 3 & 4 & $\begin{array}{l}\text { How long have you been } \\
\text { staying here? (camp) }\end{array}$ & $\begin{array}{l}\text { Quantitative face } \\
\text { validity }\end{array}$ & $\begin{array}{l}\text { Impact } \\
\text { score }\end{array}$ & 1.45 & $\begin{array}{l}\text { Women in this study were a fixed } \\
\text { population and were not mobile/ } \\
\text { living in refugee camps }\end{array}$ \\
\hline 4 & 10 & $\begin{array}{l}\text { How many children are you } \\
\text { staying with who are not } \\
\text { your own? }\end{array}$ & $\begin{array}{l}\text { Quantitative face } \\
\text { validity }\end{array}$ & $\begin{array}{l}\text { Impact } \\
\text { score }\end{array}$ & 1.35 & $\begin{array}{l}\text { There are very few cases of adoption } \\
\text { in Islamic Republic of Iran }\end{array}$ \\
\hline 5 & $\begin{array}{c}70 \\
(a, b)\end{array}$ & $\begin{array}{l}\text { How many different sexual } \\
\text { partners have you had in } \\
\text { the past } 1 \text { month, } 6 \text { months, } \\
1 \text { year (including husband or } \\
\text { live-in partner) }\end{array}$ & $\begin{array}{l}\text { Quantitative face } \\
\text { validity }\end{array}$ & $\begin{array}{l}\text { Impact } \\
\text { score }\end{array}$ & 1.35 & $\begin{array}{l}\text { A 3-6 month period could be too } \\
\text { short for determining the number of } \\
\text { sexual partners }\end{array}$ \\
\hline 6 & 37 & $\begin{array}{l}\text { Did you start breastfeeding } \\
\text { soon after birth? }\end{array}$ & $\begin{array}{l}\text { Quantitative } \\
\text { content validity }\end{array}$ & CVR & 0.60 & $\begin{array}{l}\text { The question is unclear and } \\
\text { participants may have different } \\
\text { perceptions of "soon" }\end{array}$ \\
\hline 7 & 49 & $\begin{array}{l}\text { Where do you obtain your } \\
\text { sanitary wear from? }\end{array}$ & $\begin{array}{l}\text { Quantitative } \\
\text { content validity }\end{array}$ & CVR & 0.30 & $\begin{array}{l}\text { Women in this study were a fixed } \\
\text { population and usually obtain their } \\
\text { sanitary hygiene products from drug } \\
\text { stores or supermarkets }\end{array}$ \\
\hline
\end{tabular}

almpact scores $<1.5$ and $C V R<0.62$ for each item were considered as inadequate. $C V R=$ content validity ratio.

of participants was high-school diploma (Table 3).

Table 4 shows the ICCs for all domains separately as well as for the whole questionnaire. The overall ICC was 0.66. All domains of the Persian version of the questionnaire showed satisfactory reliability (ICC > 0.5 ), except for the domain of STIs, which was borderline $(\mathrm{ICC}=0.49)$.

\section{Discussion}

This psychometric study showed that, with slight modifications to the original questionnaire, the Persian version of the SRH Needs Assessment Questionnaire is a valid instrument to assess women's SRH needs, except in the domain of STIs, which had reliability coefficient close to but slightly below the threshold (ICC $=0.49$ ). In the study of Musavi et al. which used behavioural change theories to design a domestic tool for the evaluation of reproductive health in Iranian young people, it was shown that the reliability of the questionnaire was moderate in some domains such as HIV, STIs and use of condoms (27). The low reliability coefficient in the STI domain in our study may be due to spontaneous remission of STI symptoms in the 2-week interval between test and retest.

Some questions in the Persian version of SRH Needs Assessment Questionnaire were omitted because the target population of the Persian version of the tool are a fixed population and not the mobile/refugee camp population of the original questionnaire; for example, question no. 3 ["How long have you been staying here (camp)?"], was omitted. Furthermore, mobile (not fixed) populations and refugees often live in unstable circumstances that expose them to higher risk for SRH problems such as pregnancy complications, STIs, HIV/AIDS or gender-based violence. Thus, such questions were omitted $(28,29)$.
In this study, all "no response" options were omitted from the questionnaire because these options could increase the likelihood of the participants choosing them over other items. In a study examining the effect of an educational programme on the awareness of women attending hospitals in Bangalore about some aspects of safe motherhood, Tamrakar excluded all "none" options from the instrument in the content validity assessment. That study also provided evidence for high reliability of the instrument using Spearman correlation coefficient $(r$ $=0.98)$ and the split-half method for assessing reliability of the instrument (30). Since women's awareness about some aspects of safe motherhood had been evaluated, and usually knowledge-related questionnaire items have good integrity and homogeneity, it was possible to halve the questions in that study. However, the split-half method of reliability assessment was not appropriate in our study as the 
nature of items in each domain was different from that in the others and therefore ICC was used for assessing reliability.
Pourmarzi et al. conducted a study aiming to compare SRH education needs of youth in Tehran before and after marriage. To assess the validity of the tool, the face and content validity methods were used. In their study, the split-half method (odd-even) was used for reliability assessment and

\section{Table 2 Items modified or added in different phases of testing the Persian version of the Sexual and Reproductive Health} Needs Assessment Questionnaire

\begin{tabular}{|c|c|c|c|c|}
\hline Row & Item no. & Stage/ Phase & Original version & Persian version \\
\hline 1 & 17 & $\begin{array}{l}\text { Quantitative face } \\
\text { validity }\end{array}$ & Have you ever been pregnant? & Number of pregnancies: \\
\hline 2 & 26,27 & $\begin{array}{l}\text { Qualitative face } \\
\text { validity }\end{array}$ & $\begin{array}{l}\text { Who assisted you to deliver at the } \\
\text { health centre? Who assisted you to } \\
\text { deliver at home? }\end{array}$ & Delivery agent (in your last delivery): \\
\hline 3 & 68 & $\begin{array}{l}\text { Qualitative face } \\
\text { validity }\end{array}$ & $\begin{array}{l}\text { As far as you know, does it happen } \\
\text { in this community that women or } \\
\text { girls trade sex in order to get food, } \\
\text { protection or other things they } \\
\text { need? }\end{array}$ & $\begin{array}{l}\text { In your neighbourhood, are there any women or } \\
\text { girls who are paid for sex? }\end{array}$ \\
\hline 4 & 75 & $\begin{array}{l}\text { Qualitative face } \\
\text { validity }\end{array}$ & $\begin{array}{l}\text { Are you currently married or living } \\
\text { with a sexual partner? }\end{array}$ & Your marital status or living with sexual partner: \\
\hline 5 & 11 & $\begin{array}{l}\text { Qualitative face } \\
\text { validity }\end{array}$ & $\begin{array}{l}\text { Do you earn money from any form } \\
\text { of work? }\end{array}$ & $\begin{array}{l}\text { Occupation: } \\
\text { housewife, office employee, skilled worker }\end{array}$ \\
\hline 6 & 12 & $\begin{array}{l}\text { Qualitative face } \\
\text { validity }\end{array}$ & If yes, what kind of work do you do? & $\begin{array}{l}\text { (factory, technician), ordinary non-professional } \\
\text { worker, professional job (medical, engineering } \\
\text { etc.), farming, livestock, fishery industry, city and } \\
\text { inter-city driver, service worker, shopkeeper, } \\
\text { retiree, other (please state) }\end{array}$ \\
\hline 7 & 51 & $\begin{array}{l}\text { Qualitative face } \\
\text { validity }\end{array}$ & $\begin{array}{l}\text { What family planning methods have } \\
\text { you ever heard of? }\end{array}$ & $\begin{array}{l}\text { Abortion was omitted from contraceptive } \\
\text { methods }\end{array}$ \\
\hline 8 & 52 & $\begin{array}{l}\text { Qualitative face } \\
\text { validity }\end{array}$ & $\begin{array}{l}\text { Which family planning methods } \\
\text { have you ever used? }\end{array}$ & As above \\
\hline 9 & 53 & $\begin{array}{l}\text { Qualitative face } \\
\text { validity }\end{array}$ & $\begin{array}{l}\text { Which family planning methods are } \\
\text { you using now? }\end{array}$ & As above \\
\hline 10 & 54 & $\begin{array}{l}\text { Qualitative face } \\
\text { validity }\end{array}$ & $\begin{array}{l}\text { Which family planning methods } \\
\text { would you prefer to use? }\end{array}$ & As above \\
\hline 11 & - & $\begin{array}{l}\text { Qualitative face } \\
\text { validity }\end{array}$ & (new item) & Spouse's age was added \\
\hline 12 & - & $\begin{array}{l}\text { Qualitative face } \\
\text { validity }\end{array}$ & (new item) & Educational level of spouse was added \\
\hline 13 & - & $\begin{array}{l}\text { Qualitative face } \\
\text { validity }\end{array}$ & (new item) & Occupation of spouse was added \\
\hline 14 & -- & $\begin{array}{l}\text { Qualitative face } \\
\text { validity }\end{array}$ & (new item) & Household monthly income was added \\
\hline \multirow[t]{4}{*}{15} & 86 & $\begin{array}{l}\text { Qualitative face } \\
\text { validity }\end{array}$ & $\begin{array}{l}\text { As far as you know, can you get } \\
\text { AIDS from: mosquitoes, sex, blood } \\
\text { transfusion, hugging a person with } \\
\text { AIDS, sharing needles/injection, } \\
\text { sharing a meal with someone who is }\end{array}$ & $\begin{array}{l}\text { Incorrect options such as mosquitoes, hugging } \\
\text { and sharing a meal were eliminated since } \\
\text { participants may learn wrong ideas. Item nos. } 91 \\
\text { and } 92 \text { were eliminated and added to this item } \\
\text { as options. }\end{array}$ \\
\hline & & & & \multirow{3}{*}{$\begin{array}{l}\text { The modified question was: As far as you know, } \\
\text { through which of the following routs can you get } \\
\text { AIDS? (you can choose several options): vaginal } \\
\text { intercourse; anal intercourse; oral sex; mother } \\
\text { to fetus; breastfeeding; syringe share; blood } \\
\text { transfusion; blood products; transplantation } \\
\text { of infected tissue; shared tattooing tools, } \\
\text { circumcision, ear piercing, phlebotomy, shared } \\
\text { barber's razor; other (please state). }\end{array}$} \\
\hline & $91(\mathrm{a})$ & & $\begin{array}{l}\text { Can a pregnant woman infected with } \\
\text { HIV or AIDS transmit the virus to her } \\
\text { unborn child? }\end{array}$ & \\
\hline & $91(b)$ & & $\begin{array}{l}\text { Can a woman with HIV or AIDS } \\
\text { transmit the virus to her newborn } \\
\text { child through breastfeeding? }\end{array}$ & \\
\hline
\end{tabular}


Table 2 Items modified or added in different phases of testing the Persian version of the Sexual and Reproductive Health Needs Assessment Questionnaire (continued)

\begin{tabular}{|c|c|c|c|c|}
\hline Row & $\begin{array}{l}\text { Item } \\
\text { no. }\end{array}$ & Stage/ Phase & Original version & Persian version \\
\hline \multirow[t]{3}{*}{16} & \multirow[t]{3}{*}{88} & \multirow[t]{3}{*}{$\begin{array}{l}\text { Qualitative content } \\
\text { validity }\end{array}$} & $\begin{array}{l}\text { Do you worry that you could get } \\
\text { HIV? }\end{array}$ & $\begin{array}{l}\text { What is the likelihood of your being infected } \\
\text { with HIV/AIDS by next year?: } \\
\text { not at all; very little; little; moderate; high; very } \\
\text { high; I am HIV positive; I don't know }\end{array}$ \\
\hline & & & (new item) & $\begin{array}{l}\text { What are your reasons for not being at risk? } \\
\text { (you can select more than one option): I have } \\
\text { not had any sexual contact; I have had only } \\
\text { one sexual partner; I regularly use condom; } \\
\text { my partner is faithful; I do not share needles; } \\
\text { I am not in contact with infected blood, } \\
\text { or have not received infected blood; I am } \\
\text { careful in choosing a partner; I have had HIV } \\
\text { testing }\end{array}$ \\
\hline & & & (new item) & $\begin{array}{l}\text { What are your reasons for being at risk of } \\
\text { getting AIDS? (you can select more than one } \\
\text { option): I have multiple sexual partners; I am } \\
\text { not faithful to my partner; I am suffering from } \\
\text { sexually transmitted diseases; my husband } \\
\text { or sexual partner is HIV/AIDS infected; I } \\
\text { have had unprotected sexual contact; I used } \\
\text { drugs; I have been raped; other (please } \\
\text { specify) }\end{array}$ \\
\hline 17 & 90 & $\begin{array}{l}\text { Qualitative face } \\
\text { validity }\end{array}$ & $\begin{array}{l}\text { As far as you know, what can a } \\
\text { person do to avoid getting AIDS? }\end{array}$ & $\begin{array}{l}\text { These questions were turned into one question } \\
\text { (no. 86) }\end{array}$ \\
\hline 18 & 91 & $\begin{array}{l}\text { Qualitative face } \\
\text { validity }\end{array}$ & $\begin{array}{l}\text { Can a pregnant woman infected with } \\
\text { HIV or AIDS transmit the virus to her } \\
\text { unborn child? }\end{array}$ & \\
\hline 20 & 99 & $\begin{array}{l}\text { Qualitative face } \\
\text { validity }\end{array}$ & $\begin{array}{l}\text { As far as you know, does it happen in } \\
\text { this community (camp) that women } \\
\text { or girls are forced to have sex against } \\
\text { their will? }\end{array}$ & $\begin{array}{l}\text { Has any women or girls around you been } \\
\text { forced into having sex? }\end{array}$ \\
\hline 21 & 103 & $\begin{array}{l}\text { Qualitative face } \\
\text { validity }\end{array}$ & $\begin{array}{l}\text { Have you ever been forced to have } \\
\text { sex? }\end{array}$ & $\begin{array}{l}\text { Have you ever been forced into having sex by } \\
\text { people other than your spouse or partner? }\end{array}$ \\
\hline 22 & 104 & $\begin{array}{l}\text { Qualitative face } \\
\text { validity }\end{array}$ & $\begin{array}{l}\text { During the past } 12 \text { months, did any } \\
\text { of your sexual partner(s) force you to } \\
\text { have sex with them even though you } \\
\text { did not want to have sex? }\end{array}$ & $\begin{array}{l}\text { Have you ever been forced into having sex by } \\
\text { your spouse or partner? }\end{array}$ \\
\hline 23 & 108 & $\begin{array}{l}\text { Qualitative face } \\
\text { validity }\end{array}$ & $\begin{array}{l}\text { Are there things that you think might } \\
\text { be helpful to you in coping with your } \\
\text { experiences of forced sex? }\end{array}$ & $\begin{array}{l}\text { What do you think might help prevent violent/ } \\
\text { forced sex against women? }\end{array}$ \\
\hline 24 & 109 & $\begin{array}{l}\text { Qualitative face } \\
\text { validity }\end{array}$ & $\begin{array}{l}\text { Since arriving in this community, has } \\
\text { anyone ever hit you? }\end{array}$ & Have you been battered in the past 12 months? \\
\hline 25 & 114 & $\begin{array}{l}\text { Qualitative face } \\
\text { validity }\end{array}$ & $\begin{array}{l}\text { Are there things that you think might } \\
\text { be helpful to you in coping with your } \\
\text { experiences of physical violence? }\end{array}$ & $\begin{array}{l}\text { What can be done to prevent physical violence } \\
\text { against women? }\end{array}$ \\
\hline 9 & 63 & $\begin{array}{l}\text { Quantitative } \\
\text { content validity }\end{array}$ & $\begin{array}{l}\text { Have you ever used a female } \\
\text { condom? }\end{array}$ & Have you ever used a condom? \\
\hline 10 & 64 & $\begin{array}{l}\text { Quantitative } \\
\text { content validity }\end{array}$ & $\begin{array}{l}\text { If "no", why have you not used a } \\
\text { female condom? }\end{array}$ & If "no", why have you not used a condom? \\
\hline 11 & 65 & $\begin{array}{l}\text { Quantitative } \\
\text { content validity }\end{array}$ & $\begin{array}{l}\text { Do you know any place or person } \\
\text { where you can obtain female } \\
\text { condom? }\end{array}$ & $\begin{array}{l}\text { Do you know any place or person where you } \\
\text { can obtain condom? }\end{array}$ \\
\hline & 66 & $\begin{array}{l}\text { Quantitative } \\
\text { content validity }\end{array}$ & $\begin{array}{l}\text { Which places or persons do you } \\
\text { know where you can obtain female } \\
\text { condom? }\end{array}$ & $\begin{array}{l}\text { Which places or persons do you know where } \\
\text { you can obtain condom? }\end{array}$ \\
\hline
\end{tabular}




\begin{tabular}{|c|c|c|c|}
\hline \multicolumn{4}{|c|}{$\begin{array}{l}\text { Table } 2 \text { Items modified or added in different pha } \\
\text { Needs Assessment Questionnaire (concluded) }\end{array}$} \\
\hline Row & $\begin{array}{l}\text { Item } \\
\text { no. }\end{array}$ & Original version & Persian version \\
\hline 13 & - & $\begin{array}{l}\text { Quantitative content (new item) } \\
\text { validity }\end{array}$ & Have you ever had unwanted pregnancy? \\
\hline 14 & - & $\begin{array}{l}\text { Quantitative content (new item) } \\
\text { validity }\end{array}$ & If yes, how many times? \\
\hline 14 & - & $\begin{array}{l}\text { Quantitative content (new item) } \\
\text { validity }\end{array}$ & $\begin{array}{l}\text { Have you ever had termination(s) of } \\
\text { pregnancy? }\end{array}$ \\
\hline 15 & - & $\begin{array}{l}\text { Quantitative content (new item) } \\
\text { validity }\end{array}$ & If yes, how many times? \\
\hline \multirow[t]{3}{*}{16} & - & $\begin{array}{l}\text { Quantitative content (new item) } \\
\text { validity }\end{array}$ & $\begin{array}{l}\text { Did you use contraception, before your } \\
\text { unwanted pregnancy? }\end{array}$ \\
\hline & & $\begin{array}{l}\text { Quantitative } \\
\text { content validity }\end{array}$ & $\begin{array}{l}\text { If yes, what method of contraception did you } \\
\text { use? }\end{array}$ \\
\hline & & $\begin{array}{l}\text { Quantitative } \\
\text { content validity }\end{array}$ & $\begin{array}{l}\text { If no, what was your reason for not using any } \\
\text { contraception method? }\end{array}$ \\
\hline
\end{tabular}

the Spearman correlation coefficient was 0.96 (31). Researchers compared youths' views on 11 general topics in the form of educational needs for SRH before and after marriage, while the SRH needs were not investigated in detail in their study. Meanwhile, in the present study, SRH needs were separately assessed using a standard questionnaire in 6 domains, and each domain included a number of questions about women's needs. It seems

Table 3 Demographic characteristics of women participants in the test-retest of the Persian version of the Sexual and Reproductive Health Needs Assessment Questionnaire in Sari, Islamic Republic of Iran $(n=60)$

\begin{tabular}{lc} 
Variable & Value \\
Age (years) [mean (SD)] & $31.0(7.8)$ \\
Age at marriage (years) [mean (SD)] & $34.2(9.6)$ \\
Husband's age (years) [mean (SD)] & $20.6(5.5)$ \\
Educational level [no. (\%)] & \\
$\quad$ Less than high school & $20(33.3)$ \\
High school diploma & $23(38.4)$ \\
$\quad$ College education & $17(28.3)$ \\
Occupational status [no. (\%)] & \\
$\quad$ Housewife & $45(76.3)$ \\
$\quad$ Employed & $15(23.7)$ \\
Husband's educational level [no. (\%)] & $19(31.7)$ \\
Less than high school & $25(41.7)$ \\
High school diploma & $16(26.6)$ \\
$\quad$ College education & \\
\hline
\end{tabular}

that, although the subjects of these 2 studies are generally similar, different tools were used in each study in view of the aims of the two studies. It appears the use of psychometric tools in our study was more suitable for assessing SRH needs.

In a study by Haddad et al. to design the Arabic version of a questionnaire about violence against women in Jordan, the standard NorVold Domestic Abuse Questionnaire 


\begin{tabular}{|c|c|c|c|}
\hline Domain & $\begin{array}{l}\text { Intra-class } \\
\text { correlation } \\
\text { coefficient }\end{array}$ & $95 \% \mathrm{Cl}$ & $P$-value \\
\hline Safe motherhood & 0.81 & $0.68-0.88$ & $<0.001$ \\
\hline Family planning & 0.71 & $0.52-0.83$ & $<0.001$ \\
\hline Sexual history & 0.99 & $0.98-0.99$ & $<0.001$ \\
\hline Sexually transmitted infections & 0.49 & $0.13-0.70$ & 0.007 \\
\hline HIV/AIDS & 0.67 & $0.45-0.80$ & $<0.001$ \\
\hline Violence & 0.60 & $0.33-0.76$ & $<0.001$ \\
\hline Total & 0.66 & $0.43-0.80$ & $<0.001$ \\
\hline
\end{tabular}

$C l=$ confidence interval.

This is another limitation of this study. Other limitations of this study stem from the given setting and population of the study, as in our study the SRH needs of women in rural areas, of men or of young people in Mazandaran were not assessed. We suggest that special and contextualized tools be developed and used for these groups or communities in Persian-speaking regions. reliability. This questionnaire can be used by policy-makers, managers, researchers and health-care providers to assess the SRH needs of Iranian women and plan and design strategies to meet them.

\section{Acknowledgements}

This article is derived from the thesis of Soghra Khani for fulfilment of a PhD degree in Reproductive Health at Tarbiat Modares University (Faculty of Sciences), Tehran, Islamic Republic of Iran.

We also wish to express our gratitude to the team members of New Dimension Consulting-Zimbabwe, including Dr Victoria James, for giving us permission to make the Persian version of the questionnaire.

Funding: This study was approved and funded by the research council of Tarbiat Modares University (Faculty of Medical Sciences), Tehran, Islamic Republic of Iran.

Competing interests: None declared.

\section{References}

1. Witkin BRAJ. Planning and conducting needs assessments: a practical guide. Thousand Oaks (CA): Sage Publications, Inc; 1995.

2. Lusti-Narasimhan M, Cottingham J, Berer M. Ensuring the sexual and reproductive health of people living with HIV: policies, programmes and health services. Reprod Health Matters. 2007;15 May(29 Suppl):4-26.

3. Lopez-Claros A, Zahidi S. Women's empowerment: measuring the global gender gap. Geneva: World Economic Forum; 2005.

4. Bharat S, Mahendra VS. Meeting the sexual and reproductive health needs of people living with HIV: challenges for health care providers. Reprod Health Matters. 2007 May;15(29) Suppl:93-112. PMID:17531750

5. Iranian health houses open the door to primary care. Bull World Health Organ. 2008 Aug;86(8):585-6. PMID:18797612

6. Defining sexual health. Report of a technical consultation on sexual health, 28-31 January 2002, Geneva. Geneva: World Health Organization; 2006 (http://www.who.int/reproductivehealth/publications/sexual_health/defining_sexual_ health.pdf, accessed 1 October 2014).

7. Cavanagh S, Chadwick K. Health needs assessment: a practical guide. London: National Institute for Health and Clinical Excellence; 2005.

8. Global strategy for women's and children's health. New York: United Nations; 2010.

9. Aghdak P, Majlesi F, Zeraati H. EftekharArdebili H. Reproductive related needs in marriage volunteers. Payesh. 2009;8(4):379-85.
10. Simbar M, Tehrani FR, Hashemi Z. Sexual-reproductive health belief model of college students. Iranian South Medical Journal (Bushehr University of Medical Sciences). 2004;7(1):70-8.

11. Shahhosseini Z, Abedian K. Iranian university students' perceived reproductive health needs. Int J Adolesc Med Health. 2014;26(3):339-44 PMID:24096440

12. Hajizadeh S, Nejat S, Majdzadeh SR, Setayesh HR, Guya MM. Fertility Intentions of Patients who reffered to behavioral clinics of universities of medical sciences in Tehran. Journal of Isfahan Medical School. 2011;29(167):1-10.

13. Mosavi SA, Babazadeh R, Najmabadi KM, Shariati M. Assessing Iranian adolescent girls' needs for sexual and reproductive health information. J Adolesc Health. 2014 Jul;55(1):107-13. PMID:24560307

14. Sexual and reproductive health (SRH) needs assessment among mobile and vulnerable population (MVP) communities in Zimbabwe. Study report. Zimbabwe: New Dimension Consulting (pvt) Ltd; 2008 (http://s3.amazonaws.com/ zanran_storage/www.humanitarianreform.org/ContentPages/221068444.pdf, accessed 1 October 2014).

15. Baral S, Poteat T, Stromdahl S, Writz A, Guadamuz T, Beyrer C. Worldwide burden of HIV in transgender women: a systematic review and meta-analysis. Lancet. 2013;13(March):214-22. PMID:23260128

16. CDC Reproductive health assessment questionnaire for conflict-affected women. Atlanta (GA): Centers for Disease Control and Prevention; 2011 (http://www.cdc.gov/reproductivehealth/Global/PDFs/RHAToolkitQuestionnaireUp- 
datedSeptember2011_FINAL_Tag508.pdf, accessed 1 October 2014).

17. Rashidian A. Health observatory: first report. I.R. Iran multipleindicator demographic and health survey 2010. Tehran: Ministry of Health; 2012.

18. Process of translation and adaptation of instruments [Internet] Geneva: World Health Organization; 2013 (http://www.who. int/substance_abuse/research_tools/translation/en/, accessed 1 October 2014).

19. Ljungberg AK, Fossum B, Fürst CJ, Hagelin CL. Translation and cultural adaptation of research instruments - guidelines and challenges: an example in FAMCARE-2 for use in Sweden. Inform Health Soc Care. 2014 Jan 6;2014:22. PMID:24393044

20. Polit D, Beck C. Chapter 18. Developing and testing self-report scales. In: Nursing research: generating and assessing evidence for nursing practice. Philadelphia (PA): Wolters Kluwer/ Lippincott Williams and Wilkins; 2012. pp. 370-2.

21. Polit DF, Beck CT. The content validity index: are you sure you know what's being reported? Critique and recommendations. Res Nurs Health. 2006 Oct;29(5):489-97. PMID:16977646

22. Lawshe C. A quantitative approach to content validity Personnel Psychology. 1975;28:563-75.

23. Waltz C, Bausell R. Nursing research: design, statistics and computer analysis. Philadelphia (PA): FA Davis Company; 1981.</unknown

24. Taylor P. An introduction to intraclass correlation that resolves some common confusions [Internet]. Boston (MA): University of Massachusetts Boston; 2014 (www.faculty.umb.edu/ pjt/09b.pdf, accessed 1 October 2014).

25. Putting women first: ethical and safety recommendations for research on domestic violence against women. Geneva: World Health Organization; 2001 (http://www.who.int/gender/violence/womenfirtseng.pdf, accessed 1 October 2014).
26. Report of the International Conference on Population and Development. Cairo, 5-15 September 1994. New York (NY): United Nations; 1995 (http://www.unfpa.org/webdav/site/ global/shared/documents/publications/2004/icpd_eng.pdf, accessed 1 October 2014).

27. Musavi A, Keramat A, Vakilian K, Vardanjani SE. Development and adaptation of Iranian youth reproductive health questionnaire. ISRN Obstet Gynecol. 2013 Jul 31;2013:950278. PMID:23984084

28. Krause SK, Jones RK, Purdin SJ. Programmatic responses to refugees' reproductive health needs. Int Fam Plan Perspect. 2000;26(4)181-7.

29. Chankin W, Rosenbaum S. Women's health and health care reform. The key role of comprehensive reproductive health care. New York (NY): Mailman School of Public Health, Colombia Universty; 2010 (http://www.jiwh.org/attachments/ Women\%20and\%20Health\%20Care\%20Reform.pdf, access 13 October 2014).

30. Tamrakar A. A study to evaluate the effectiveness of planned teaching program on knowledge of primi gravidae regarding selected aspects of safe motherhood in selected hospitals in Kolar, Karnataka [MSc thesis]. Kolar, India: Pavan College of Nursing; 2007.

31. Purmarzi D, Rimaz S, Khoei E, Dodaran M, Mehran A, Safari $S$. Educational needs related to reproductive health in young people before marriage. Journal of Health College and Health Researches Institutes. 2011;10(10):11-23.

32. Haddad LG, Shotar A, Younger JB, Alzyoud S, Bouhaidar CM. Screening for domestic violence in Jordan: validation of an Arabic version of a domestic violence against women questionnaire. Int J Womens Health. 2011;3:79-86. PMID:21445377

33. Oluwatayo JA. Validity and reliability issues in educational research. Journal of Educational and Social Research. 2012;2(2):391-400. 